(C) Парвин Гафарян, Сахар Таджбахш, 2019, Океанологические исследования, 2019, Том 47, № 5, C. $12-25$

\title{
SIGNATURE OF THE CLIMATE CHANGE IN THE SOUTH CASPIAN BASIN AND COASTAL AREA
}

\author{
Parvin Ghafarian ${ }^{1}$, Sahar Tajbakhsh ${ }^{2}$ \\ ${ }^{1}$ Iranian National Institute for Oceanography and Atmospheric Science, Tehran, \\ Iran,e-mail:p.ghafarian@inio.ac.ir \\ ${ }^{2}$ Atmospheric Science and Meteorological Research Center, Tehran, Iran \\ Submitted 01.02.2019, accepted 06.12.2019
}

\begin{abstract}
The climate change is the main issue in recent decades. Marine and coastal areas are deeply affected by climate change. To investigate the effect of climate change in the southern coast of the Caspian Sea, the variations of main meteorological parameters such as anomaly of minimum and maximum temperature, precipitation, sea surface temperature and, also the frequency of foggy, hazy and dusty days are examined in a 40-year period from 1979 to 2018 (anomalies with respect to the 1981-2010 baseline). The results of the study showed that the significant increasing trend in temperature in all stations that located in industrial and urban area. There is no significant change in precipitation due to complex structure of this parameter in the South Caspian Sea areas. The lake effect and topography play as a key role in generation of precipitation than large scale systems. Also there is highly significant increasing trend of sea surface temperature in South Caspian Sea which is a result of the effects of global warming in that region. There is also an increase in the occurrence of the rare dust phenomenon in that area. The increasing trend of hazy days was observed in all areas, particularly in industrial zones that can affect some meteorological parameters.
\end{abstract}

Keywords: Caspian Sea, Climate change, Temperature anomaly, Dust, Fog, ERA5

\section{Introduction}

Since the beginning of the industrial revolution, the increased emissions of carbon dioxide, methane and other greenhouse gases have caused the disturbance of the average global and regional climate conditions. The average surface temperature has been increased in recent years, which has had many effects on all biological and non-biological communities. The increase in temperature, decrease in snow and ice cover, recession of sea and mountain ices, prolongation of growth seasons, early onset of spring in the northern hemisphere, increase in the frequency of extreme precipitation occurrences, and more than 25 thousand other changes in the biological and physical indicators are consistent with the global warming (Rosenzweig et al., 2008). For many years, the climate change studies have been possible using the output of the general atmosphere circulation models and the scenarios released by the Intergovernmental Panel on Climate Change (IPCC). The climate change projections have been reviewed in IPCC by virtue of the increase in the anthropogenic greenhouse gas and aerosol emissions (IPCC, 2013). Time series and variations in temperature and precipitation play an effective role in the climate change 
mitigation and adaptation programs, and the access to long-term climate data is essential for such analysis. World Meteorological Organization (WMO), issued a full report on the State of the Climate in 2017. This report provided a comprehensive overview of temperature variability and trends, high-impact events and many other relevant indicators of climate change. Figure 1 shows the differences of 2017 temperature from long term average. It can be seen the $1-2^{\circ} \mathrm{C}$ temperature raising in Iran including southern shore of Caspian Sea. According WMO report 2016 and 2017 years are the warmest years after industrial revolution.

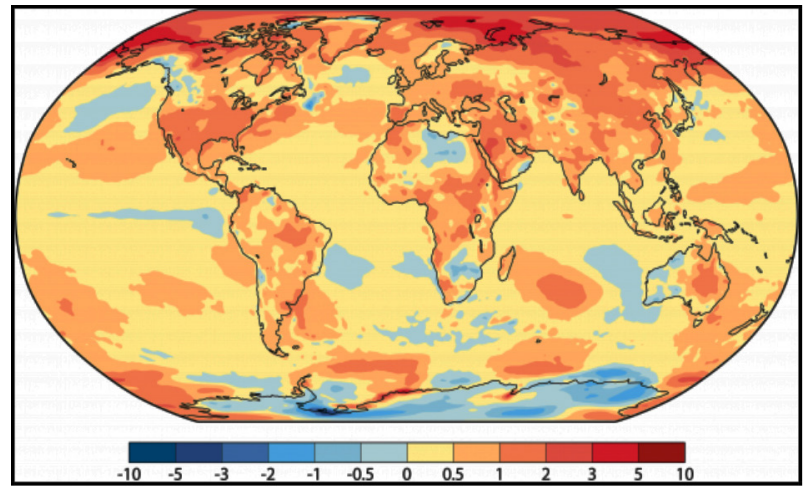

Figure 1. Differences of 2017 temperature $\left({ }^{\circ} \mathrm{C}\right)$ from the 1981-2010 average.

Because of the importance of climate change impacts in operational activates, many scientific studies have focused on the assessment of climate change impacts in the past two decades (Sansom, Renwick 2007; Petrow, Merz 2009; Cuo et al., 2011; Kay, Jones 2012; Li et al., 2016). The effects of climate change on extreme rainfall (Kendon et al. 2008; Yang et al., 2010; Min et al., 2013; D.-L. Zhang et al., 2013; H. Zhang et al., 2013), drought, floods, and sea level have investigated in many studies. Zang et. al. (2013) developed a combined probability model to evaluate the impact of climate change on waterlogging in Southern China. They showed that most modeling results predict an increase in temperature and extreme precipitation.

A study in the Marsyangdi river basin in Nepal was carried out using CanESM2 data that were downscaled with the SDSM model and the new RCP scenarios, which showed the temperature rise up to 2.29 and $3.43^{\circ} \mathrm{C}$ for the maximum and minimum temperatures until the 2090's (Khadka and Pathak, 2016). A research in Egypt was also performed with similar data, which showed an increase in the minimum temperature from 1.25 to $2.57^{\circ} \mathrm{C}$ and in the maximum temperature within $0.88-1.57^{\circ} \mathrm{C}$ (Sayad et al., 2016). In the Nile river basin, the results of the temperature variation study using several models of general circulation of atmosphere and CanESM 2 data and two SDSM and LARSWG downscaled models found the increased temperatures from 0.4 to $4.3^{\circ} \mathrm{C}$ for the maximum temperatures and 0.3 to $4.1^{\circ} \mathrm{C}$ for the minimum temperature until 2100 (Mekonnen, Disse, 2016). In the southern coast of the Caspian Sea, various analysis have also been carried out on the effects of climate change regarding the study of atmosphere and ocean parameters. Molavi et al. (2015) studied the temperature and precipitation variations in the southwestern coast of the Caspian Sea and showed their relationship with important teleconnections. The 
southern coast of the Caspian Sea, due to the subtropical wet climate, is the hub for rice cultivation in Iran from the agricultural point of view (Darzi, Karandish, 2016; Kosarev, 2005). In addition, it is a significant area in terms of biodiversity (Akhani et al., 2010). Therefore, the study and analysis of climate change and the occurrence of hazardous phenomena in the southern coast of the Caspian Sea as part of existing global changes play an important role in the mitigation and adaptation programs.

The southern coastline of Caspian Sea has an important role in regional climate due to the environmental, continental and marine effects. The changes in the position of these coastlines have led to some damages. The changes of water level that come from the land, the differences in the land sediment levels and the situation of erosion in the coastline's sediments such as continental factors and the changes of sea level and the patterns of current and Caspian Sea waves are the some changes that occur in Caspian Sea's coastlines.

Ghodrati et al. (2015) investigated the climate change impact of the Caspian Sea in relevant to the position of Southwesterly Caspian Sea coastlines. They showed the Guilan's coastline progress under the sea erosion happened in Astaneh-Ashrafiye, Talesh, Anzali, Lasko-kelaye and Roudsar. Berg and Hall (2015) Showed climate change impacts on extreme precipitations in California. They analyzed variation of mean and extreme precipitation amounts in wet season for several time scales using rain data of 34 Global climate models and showed there are no considerable changes between 2020 to 2060 and estimated considerable changes between 2060 to 2090 .

Hoogewind et al. (2017) used the WRF high resolution model in the United States for the 1971-2000 and 2071-2100 periods. The simulation results showed that the proxies for hazardous convictions would be increased by the end of the XXIst century, so that the greatest absolute increase would be occurred at daily frequency during the spring and summer.

Simpkins et al. (2014) also studied the climate change relationship in the south hemisphere extratropical cyclones and showed that variations in the Atlantic Ocean surface temperature play a key role.

Trapp and Hoogewind (2016) also re-examined the extreme tornadoes events in 2016 using numerical prediction models to find the role of anthropogenic climate changes in that events. They applied the temperature, wind, pressure and humidity changes to the models and observed that the decreased CIN and increased lifting simultaneously strengthen the very strong tornadoes.

The study of atmospheric conditions and the occurrence of weather phenomena in the southern coast of the Caspian Sea with regard to the climate change and global warming is one of the issues discussed in this paper. Therefore, in section 2, the data and methods will be introduced. In section 3, the variations in some important atmospheric parameters and weather phenomena are analyzed. Finally, in section 4, the results of this study are presented. 


\section{Methodology}

In order to investigate the effect of climate change in the southern coast of the Caspian Sea, the trends in maximum and minimum temperature anomaly and some other atmospheric parameters such as precipitation anomaly ,number of fogy, dusty and hazy days are examined for a number of stations in the southern coast of the Caspian Sea. Therefore, the study area is the southern coast of the Caspian Sea in Iran, which is restricted to $49-54^{\circ} \mathrm{E}$ and $36-40^{\circ} \mathrm{N}$ (Figure 2).

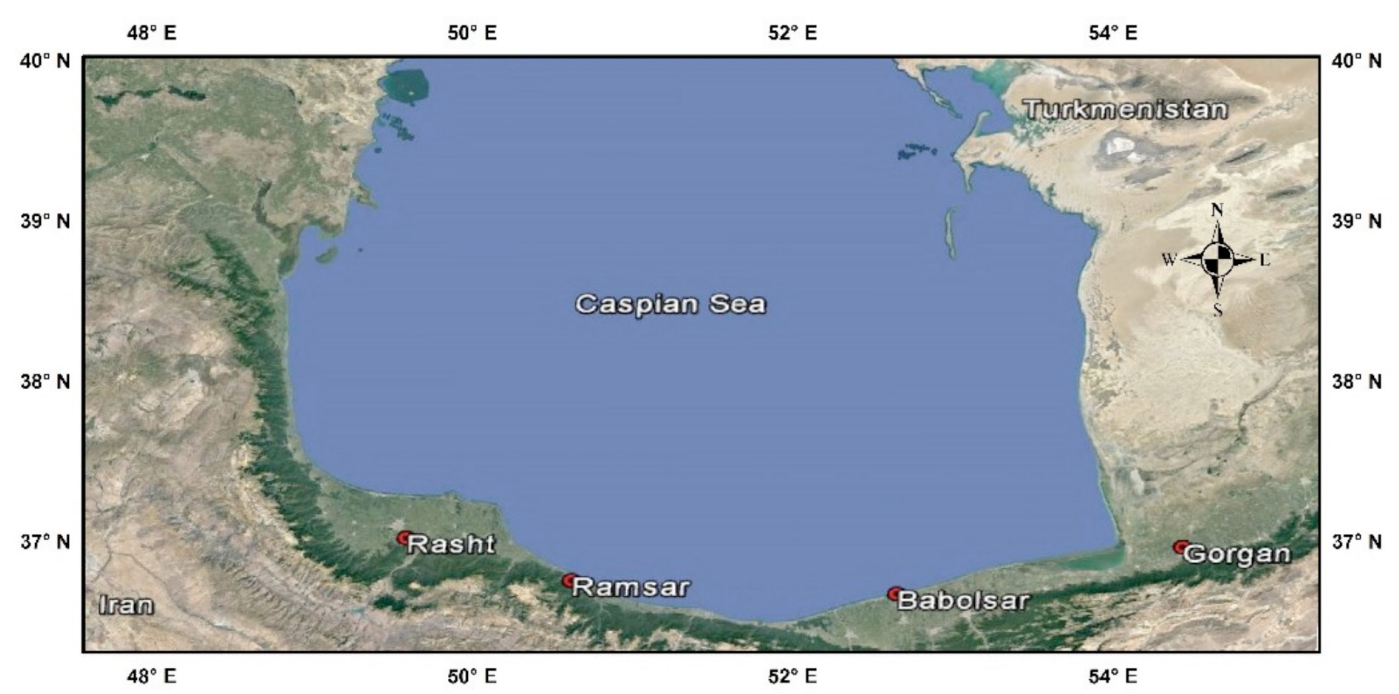

Figure 2. Studied area including Rasht, Ramsar, Babolsar and Gorgan meteorological stations in southern coast of Caspian Sea.

In this area, according to available data, the variables considered in the Rasht, Ramsar, Babolsar and Gorgan stations are investigated; the details of them are given in Table 1. Rasht and Goragan cities are industrial, whereas the babolsar and Ramsar are urban areas.

Table 1. The characteristic of study stations in the southern coast of the Caspian Sea.

\begin{tabular}{|c|c|c|c|}
\hline Station name & Latitude $\left({ }^{\circ} \mathrm{N}\right)$ & Longitude $\left({ }^{\circ} \mathrm{E}\right)$ & Elevation $(\mathrm{m})$ \\
\hline Rasht & 37.2 & 49.65 & -8.6 \\
\hline Ramsar & 36.90 & 50.67 & -20 \\
\hline Babolsar & 36.72 & 52.65 & -21 \\
\hline Gorgan & 36.90 & 54.4 & 00 \\
\hline
\end{tabular}

The study variables are maximum and minimum temperature at $2 \mathrm{~m}$ above ground level, as well as the annual precipitation, and the study period is 40-year from 1979 to 2018 (anomalies with respect to the 1981-2010 baseline). In addition, the variations in the number of days with haze as well as the number of dusty and fogy days are investigated. Accordingly, the variations in the parameters are estimated and the role of changes in temperature and precipitation is determined, which is an important factor in climate change. The number of dusty days in this study includes the days when one of the dust observation codes including 07 to 09 and 30 to 35 has been reported at least at one of the stations. These codes are 
defined according to international standards (WMO No. 306, 2017). The observation data are obtained from the Iranian Meteorological Organization (IRIMO) database.

Since the sea surface temperature of the Caspian Sea is one of the important factors affecting air temperature and precipitation, the trend of it is investigated at southern part of the Caspian Sea. The sea surface temperature data from the latest ECMWF product, ERA5, was extracted.

The Mann-Kendall test is used to examine the trend and its significance (Mann, 1945; Kendall, 1975). The Mann-Kendall (M-K) test is a non-parametric test used to detect the presence of linear or non-linear trends in time series data. The M-K test assesses if a series is steadily increasing/decreasing or unchanging. In this research we have used of $\mathrm{p}$ symbol in trend figures as probability (significance).

\section{Discussion}

In this section, the first step is to study the trends of minimum and maximum air temperature anomaly at 2 meter above ground level, trend of precipitation anomaly, frequency of foggy, hazy and dusty days, which have long-term data available and are widely distributed across the southern coast of the Caspian Sea is investigated.

Trends of minimum temperature anomaly

The trends in the minimum temperature anomaly in Rasht, Ramsar and Babolsar stations show the increase over the 40-year period, which is significant (Figure 2-a, b, c). The highest temperature rise has occurred at Ramsar station $\left(0.67^{\circ} \mathrm{C}\right.$ per decade). Minimum temperature trend at the Gorgan station is not significant.
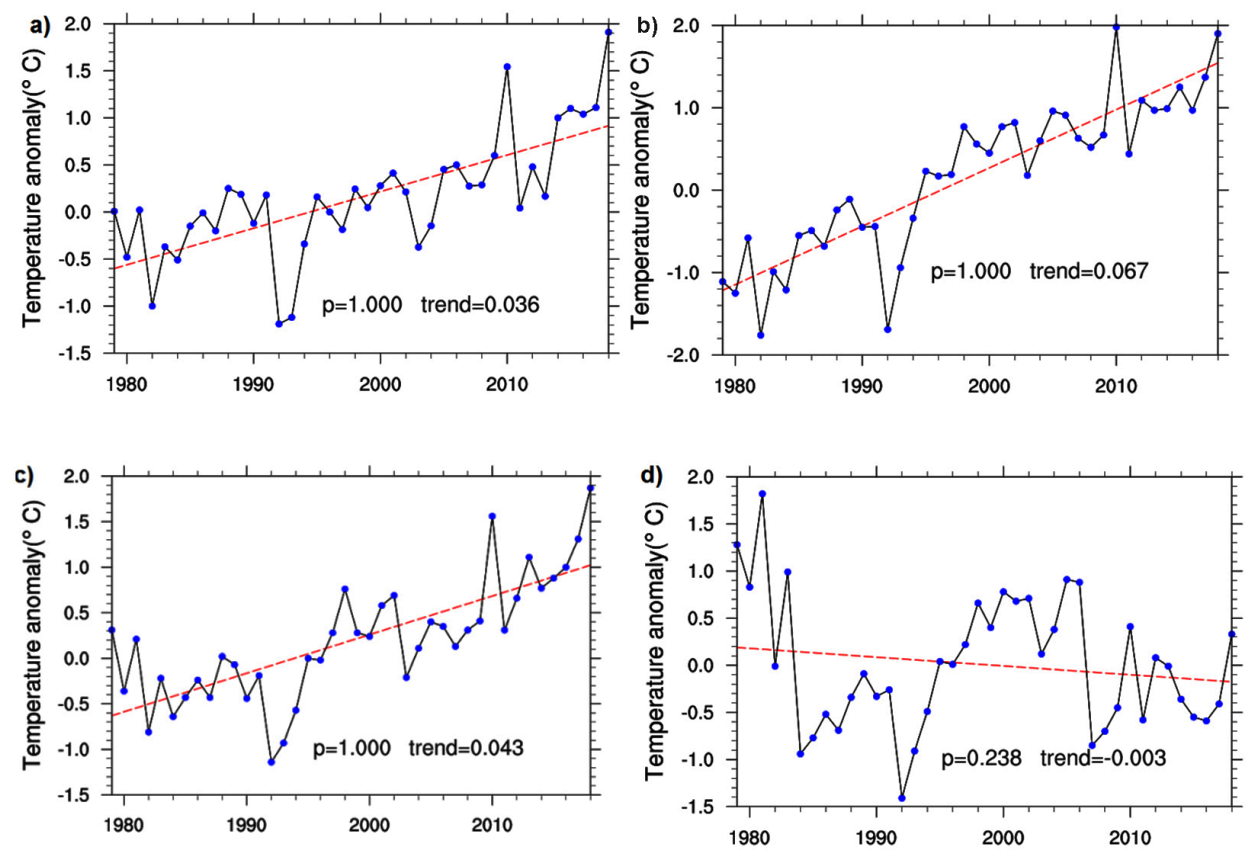

Figure 3. Minimum temperature anomaly $\left({ }^{\circ} \mathrm{C}\right)$ trend in (a) Rasht, (b) Ramsar, (c) Babolsar and (d) Gorgan stations during 1979-2018. 
Trends of Maximum temperature anomaly

The increasing trends of maximum temperature anomaly during the 40-year study period are seen at all stations (figure 4 ). The largest increase in the maximum temperature anomaly has occurred in Gorgan $\left(0.49{ }^{\circ} \mathrm{C}\right.$ per decade).
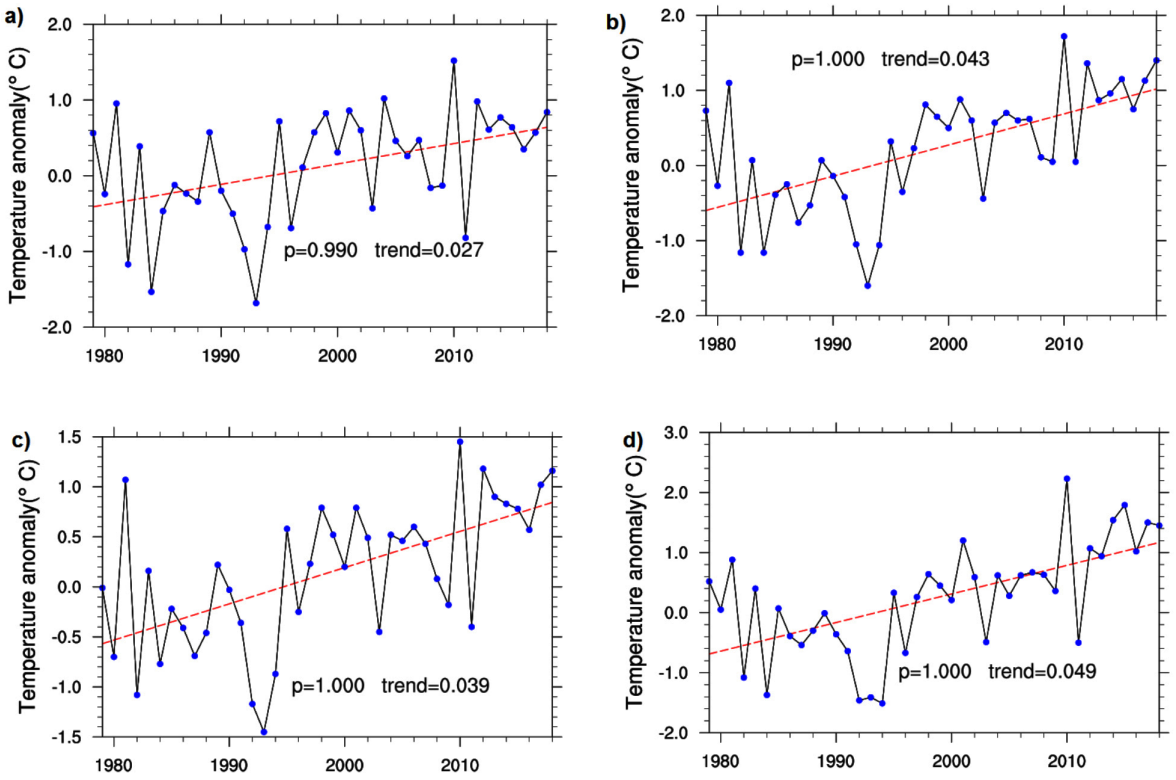

Figure 4. Similar to fig. 3 but for maximum temperature anomaly.

\section{Trends of precipitation anomaly}

Precipitation is a dominant phenomenon in the region and it has very complicated structure due to its location (between the sea and Alborz mountain range). There is no significant decreasing or increasing precipitation anomaly in Rasht, Ramsar and Babolsar stations. But there is significant decreasing trend in the Gorgan station that precipitation has decreased about 0.1 millimeters per decade (figure 5d). Precipitation distribution in the southern Caspian region is not the same. Due to the topography of the region, the wind direction on the Caspian and convergence of humidity, the southwestern regions receive more rainfall than the southeast (Ghafarian et al., 2018). Also, the Gorgan station is more distant from the sea than other stations; therefore the precipitation at this station is more affected by global warming.

\section{Trends of the frequency of foggy days}

The fog phenomenon is one of the weather hazards especially in marine and coastal areas because it affects maritime transportation. Knowledge of marine fog climatology and its variation is of utmost importance for short and long term marine weather prediction.

There is no significant decreasing or increasing of the foggy days in the Rasht and Ramsar stations. But there is increasing trend of this phenomenon in the Babolsar and Gorgan stations (figure $6 \mathrm{c}$ and $6 \mathrm{~d}$ ). Also the increase in this phenomenon has been a stronger trend in Gorgan station. 

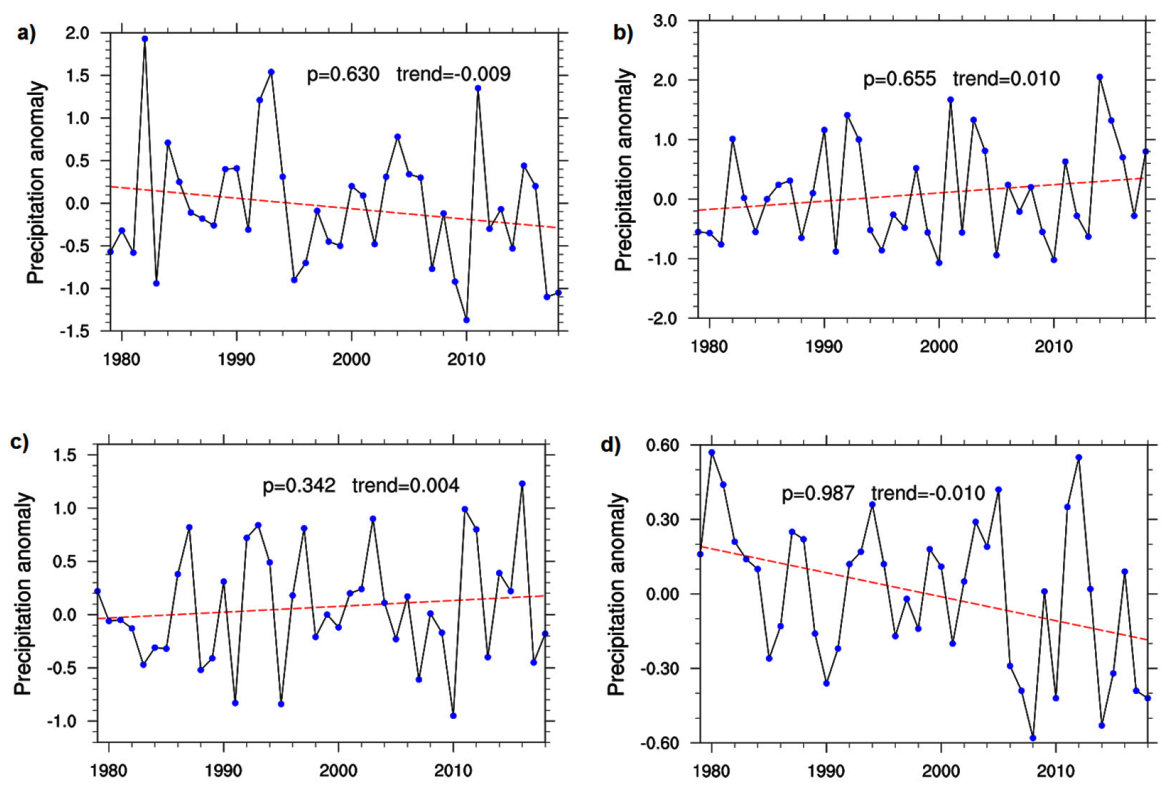

Figure 5. Similar to fig. 3 but for precipitation anomaly.
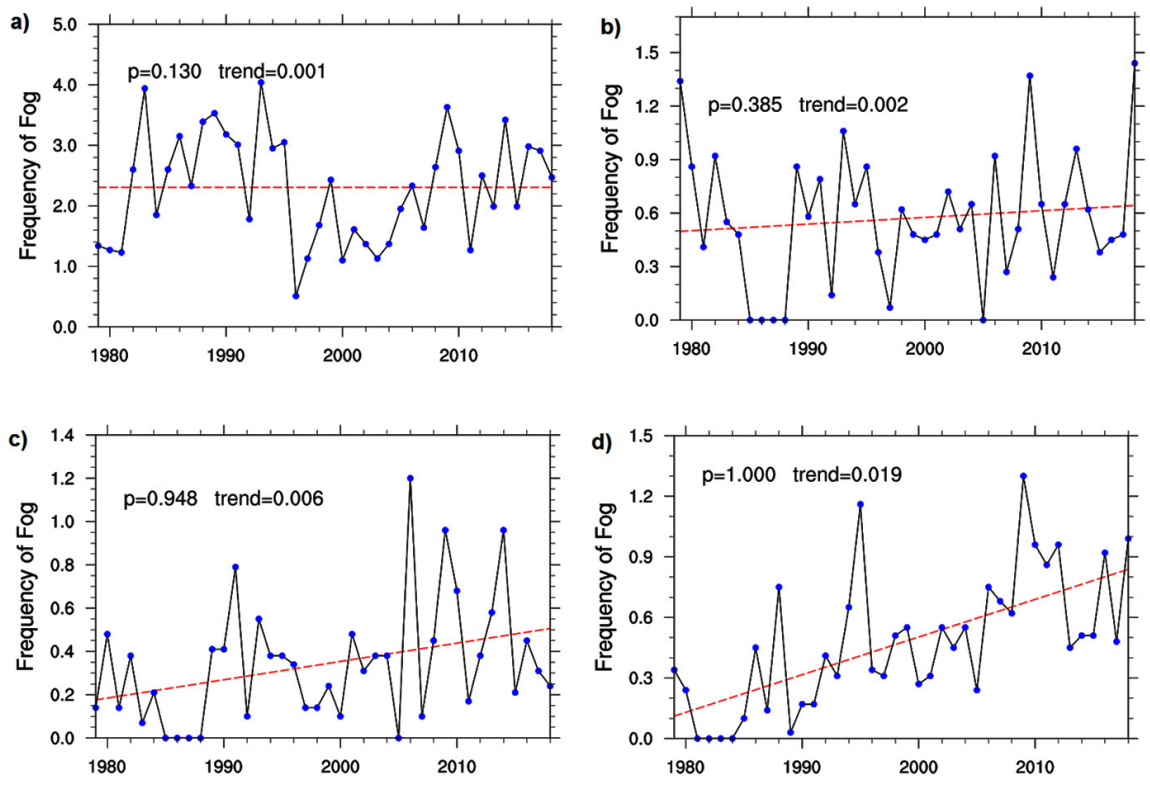

Figure 6. The frequency of foggy days in (a) Rasht, (b) Ramsar, (c) Babolsar and (d) Gorgan stations during 1979-2018.

Trends of the frequency of dusty days

The trends in the frequecy of days with dust are also studied at the 4 stations. Due to the relatively high humidity of the area, the dust phenomenon is not the predominant event of the region. In the coastal cities (Ramsar and Babolsar), this phenomenon is not reported except for several days in the 40-year period. Hence, in this section, only the data from Rasht and Gorgan stations are studied, which have a lower humidity than the other two stations. Figure $7 \mathrm{a}$ and $7 \mathrm{~b}$ indicate the variations in the frequency of dusty days in Rasht and Gorgan. As can be seen in the figure, during the last 40 years, the frequency of dusty days has been increased in the two stations, which, due to transfer of dust particles from 
other areas to these stations. In the Rasht station, after 2010, the frequency of dust event has suddenly increased. The findings indicate the transfer of dust from the Turkmenistan and the Karakum Desert to the region (Ghafarian et al., 2016).
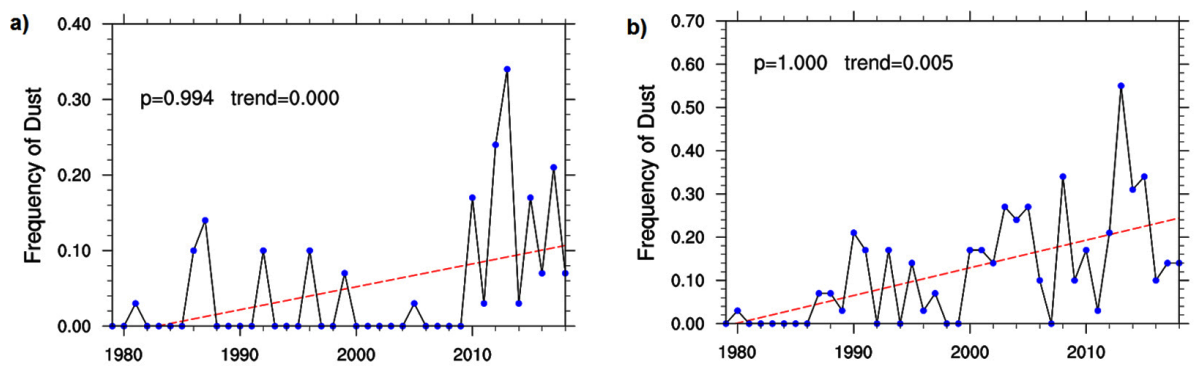

Figure 7. The frequency of dusty days in (a) Rasht, (b) Gorgan stations during 1989-2018.

Trends of sea surface temperature

Sea surface temperature is one of the most important factors in the formation of precipitation due to the lake effect. The changes in the mean sea surface temperature anomaly for the South Caspian Sea as shown in Figures 8. There is increasing trend of sea surface temperature and it is highly significant (about $0.2^{\circ} \mathrm{C}$ per decade).

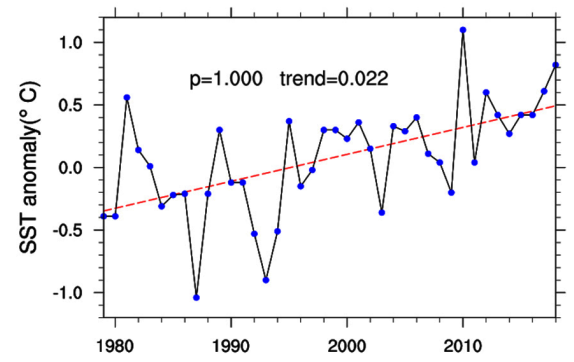

Figure 8. Average of Sea surface temperature anomaly $\left({ }^{\circ} \mathrm{C}\right)$ trend in during 1989-2018 for the south Caspian Sea.

Trends of the frequency of hazy days

Haze is a hazard in this area. Haze event can effects visibility and solar radiation. There is increasing trend of hazy days in all four stations; also the trend is highly significant. In the Gorgan stations, the frequency of haze increased about 3 events per decade. In large industrial cities such as Rasht and Gorgan, this phenomenon was more frequent than in other areas. The meteorological parameters in these two regions will be more prone to changes than other parts.

\section{Conclusion}

The aim of this study was to investigate the influence of global warming on atmospheric parameters on the southern coast of the Caspian Sea. The results of the study showed that the increasing trends of minimum and maximum temperature anomaly during the 40-year study period are seen at all stations. The only exception was the 

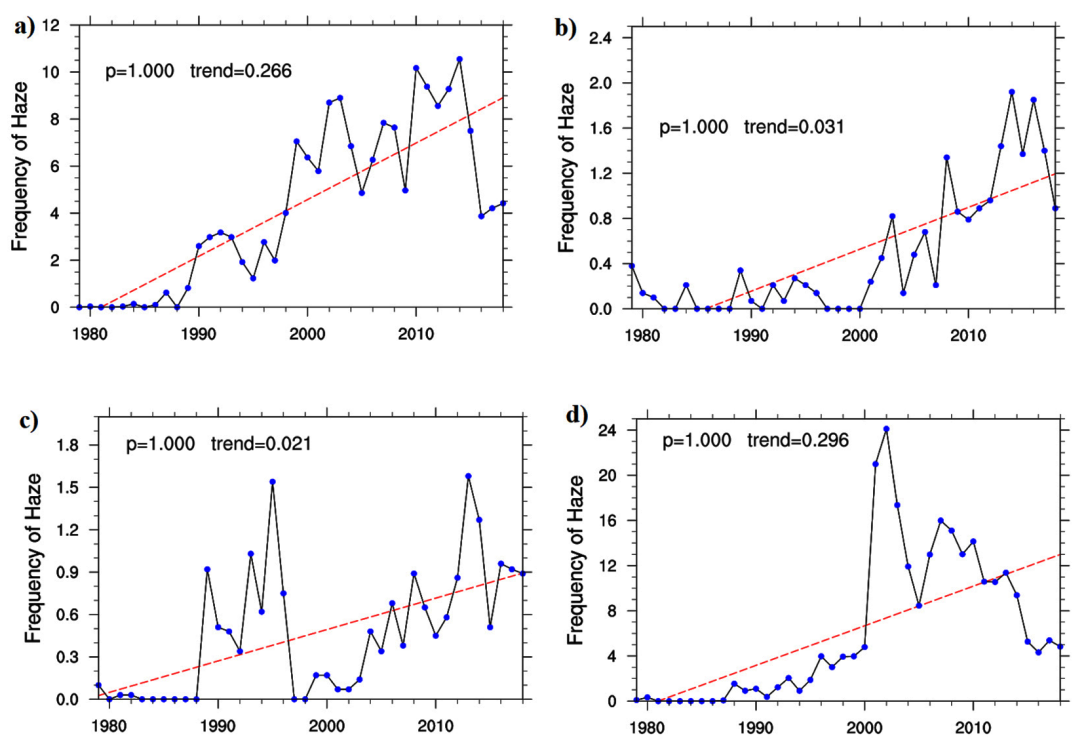

Figure 9. The frequency of hazy days in (a) Rasht, (b) Ramsar, (c) Babolsar and (d) Gorgan stations during 1979-2018.

minimum temperature in Gorgan station where no significant trend was observed. Due to the complexity of the precipitation pattern in this region and the effect of large scale and local factors in its creation, no significant trend in precipitation anomaly was observed. Only at Gorgan station was a decreasing trend of precipitation. The increasing trend of the fog phenomenon was found in the eastern regions of the study area. The phenomenon of dust, which is rare in the South of the Caspian, has grown in the region in recent years. This is due to the prolonged and severe droughts in the desert of Turkmenistan and is a sign of climate change. One indicator of climate change is the warming of seas and ocean's surface temperature. The results showed a significant increase in water surface temperature in the South Caspian Sea sector. Since the amount of rainfall and humidity in the area is due to the effect of the lake, changing the sea surface temperature may change the climate of the area in the future. The increase in haze frequency in the region indicates an increase in industrial activities and the release of greenhouse gases in the region, with the expansion of urbanization and the creation of a heat island, the rising temperature trend will accelerate in the future. Finally, apart from precipitation, other meteorological parameters and phenomena have significant changes that can show signs of global warming effects on the South Caspian Sea.

Acknowledgment This work has been financially supported by Iran National Science Foundation (INSF).

The authors would like to thank the editor and an anonymous reviewers for the precious remarks and comments that helped improve the initial version of this paper.

\section{References}

Akhani H., Djamali M., Ghorbanalizadeh A., and Ramezani E. Plant biodiversity of Hyrcanian relict forests, $N$ Iran: an overview of the flora, vegetation, palaeoecology and conservation. Pak. J. Bot., 2010, Vol. 42, pp. 231-258.

Berg N. and Hall A. Increased Interannual Precipitation Extremes over California under Climate 
Change. Journal of Climate, 2015, Vol. 28, No. 16, pp. 6324-6334.

Cuo L., Beyene T.K., Voisin N., Su F., Lettenmaier D.P., Alberti M., and Richey J.E. Effects of mid-twenty-first century climate and land cover change on the hydrology of the Puget Sound basin, Washington. Hydrol. Processes, 2011, Vol. 25, pp. 1729-1753, doi: 10.1002/ hyp.7932.

Darzi N.A. and Karandish F. Rice Cultivation Management in Mazandaran Province under Climate Change. Journal of Water Research in Agriculture, 2016, Vol. 30.3(3), pp. 333-346, doi: 10.22092/jwra.2016.107154.

Ghafarian P., Negah S., Mojtahedi M., and Abed H. Simulation of dust emission from the Turkmenistan desert to the southern coast of the Caspian Sea. Journal of Applied Geosciences Research, 2016, Vol. 15(38), pp. 141-164.

Ghafarian P., Pegahfar N., and Owlad E. Multiscale analysis of lake-effect snow over the southwest coast of the Caspian Sea (31 January-5 February 2014). Weather, 2018, Vol. 73(1), pp. 9-14.

Ghodrati A., Safaval P.A., and LashtehNeshaei M.A. Climate Change Impact of the Caspian Sea Level Changes in the Quaternary Sediment. Frontiers in Environmental Engineering, 2016, Vol. 5, pp. 1-10, doi: 10.14355/fiee.2016.05.001.

Hoogewind K.A., Baldwin M.E., and Trapp R.J. The Impact of Climate Change on Hazardous Convective Weather in the United States: Insight from High-Resolution Dynamical Downscaling. Journal of Climate, 2017, Vol. 30, No. 24, pp. 10081-10100.

IPCC. Climate Change 2013. The Physical Science Basis. Contribution of Working Group I to the Fifth Assessment Report of the Intergovernmental Panel on Climate Change, Eds: Stocker T.F., Qin D., Plattner G.-K., Tignor M., Allen S.K., Boschung J., Nauels A., Xia Y., Bex V., Midgley P.M. Cambridge, UK and New York, NY: Cambridge University Press, 2013, 1535 p., doi: 10.1017/CBO9781107415324.

Kay A.L. and Jones D.A. Transient changes in flood frequency and timing in Britain under potential projections of climate change. Int. J. Climatol., 2012, Vol. 32, pp. 489-502, doi: $10.1002 /$ joc. 2288 .

Kendall M.G. Rank Correlation Methods. Fourth Edition. Griffin, London, 1975, Zarubeznye statisticeskie issledovanija, Moskau: "Statistika“, 1975, 214 p.

Kendon E.J., Rowell D.P., Jones R.G., and Buonomo E. Robustness of future changes in local precipitation extremes. J. Climate, 2008, Vol. 21, pp. 4280-4297, doi: 10.1175/2008JCLI2082.1.

Khadka D. and PathakD. Climate Change Projection for The Marsyangdi River Basin, Nepal Using Statistical Downscaling of GCM and Its Implications in Geodisasters. Geoenvironmental Disasters, 2016, Vol. 3, pp. 15, doi: 10.1186/s40677-016-0050-0.

Li J., Chen Y.D., Zhang L., Zhang Q., and Chiew F.H.S. Future changes in floods and water availability across China:Linkage with changing climate and uncertainties. J. Hydrometeor., 2016, Vol. 17, pp. 1295-1314, doi:10.1175/JHM-D-15-0074.1.

Mann H.B. Nonparametric tests against trend. Econometrica, 1945, Vol. 13, pp. 245-259.

Mekonnen D.F. and Disse M. Analyzing The Future Climate Change of Upper Blue Nile River Basin (UBNRB) Using Statistical Down Scaling Techniques. Hydrol. Earth Syst. Sci. Discuss., 2016, doi: 10.5194/hess-2016-543.

Min S.-K., Zhang X., Zwiers F., Shiogama H., Tung Y.-S., and Wehner M. Multimodel detection and attribution of extreme temperature changes. J. Climate, 2013, Vol. 26, pp. 7430-7451, doi:10.1175/JCLI-D-12-00551.1.

Molavi-Arabshahi M., Arpe K., and Leroy S.A.G. Precipitation and temperature of the southwest Caspian Sea region during the last 55 years: their trends and teleconnections with large- 
scale atmospheric phenomena. Int. J. Climatol., 2015, Vol. 36, pp. 2156-2172, doi: 10.1002/ joc. 4483 .

Petrow T. and Merz B. Trends in flood magnitude, frequency and seasonality in Germany in the period 1951-2002. J. Hydrol., 2009, Vol. 371, pp. 129-141, doi: 10.1016/j. jhydrol.2009.03.024.

Rosenzweig C., Karoly D., Vicarelli M., Neofotis P., Wu Q., Casassa G., Menzel A., Root T.L., Estrella N., Seguin B., and Tryjanowski P. Attributing physical and biological impacts to anthropogenic climate change. Nature, 2008, Vol. 453(7193), pp. 353.

Sansom J. and Renwick J.A. Climate change scenarios for New Zealand rainfall. J. Appl. Meteor. Climatol., 2007, Vol. 46, pp. 573-590, doi: 10.1175/JAM2491.1.

Sayad T.A., Ali A.M., and Kamel A.M. Study The Impact of Climate Change on Maximum and Minimum Temperature Over Alexandria, Egypt Using Dtatisrtical Downscaling Model (SDSM). Global Journal of Advanced Research, 2016, Vol. 3, No. 8, pp. 694-712.

Simpkins G.R., McGregor Sh., Taschetto A.S., Ciasto L., and England M.H. Tropical Connections to Climatic Change in the Extratropical Southern Hemisphere: The Role of Atlantic SST Trends. Journal of Climate, 2014, Vol. 27, No. 13, pp. 4923-4936, https://doi.org/10.1175/ JCLI-D-13-00615.1.

Trapp R.J. and Hoogewind K.A. The realization of extreme tornadic storm events under future anthropogenic climate change. Journal of Climate, 2016, Vol. 29(14), pp. 5251-5265.

WMO, 2017, https://public.wmo.int/en/media/press-release/wmo-confirms-2017-among-threewarmest-years-record.

WMO, Manual on Codes International Codes, Volume I.1, Annex II to the WMO Technical Regulations, Part A - Alphanumeric Codes. WMO- No. 306, 2011 edition, Updated in 2018, ISBN: 978-92-63-10306-2.

Yang T., Shao Q., Hao Z.-C., Chen X., Zhang Z., Xu C.-Y., and Sun L. Regional frequency analysis and spatio-temporal pattern characterization of rainfall extremes in the Pearl River basin. China. J. Hydrol., 2010, Vol. 380, pp. 386-405, doi:10.1016/j.jhydrol.2009.11.013.

Zhang D.-L., Lin Y., Zhao P., Yu X., Wang S., Kang H., and Ding Y. The Beijing extreme rainfall of 21 July 2012:"Right results" but for wrong reasons. Geophys. Res. Lett., 2013, Vol. 40, pp. 1426-1431, doi: 10.1002/grl.50304.

Zhang H., Fraedrich K., Blender R., and Zhu X. Precipitation extremes in CMIP5 simulations on different time scales. J. Hydrometeor., 2013, Vol. 14, pp. 923-928, doi: 10.1175/ JHM-D-12-0181.1.

Zhang H., Wu Ch., Chen W., and Huang G. Assessing the Impact of Climate Change on the Waterlogging Risk in Coastal Cities: A Case Study of Guangzhou, South China. Journal of Hydrometeorology, 2017, Vol. 18, No. 6, pp. 1549-1562 https://doi.org/10.1175/ JHM-D-16-0157.1. 


\title{
ПРОЯВЛЕНИЯ ИЗМЕНЕНИЙ КЛИМАТА В ЮЖНО-КАСПИЙСКОМ БАССЕЙНЕ И ПРИБРЕЖНОЙ ЗОНЕ
}

\author{
Парвин Гафарян ${ }^{1}$, Сахар Таджбахш" ${ }^{2}$
}
${ }^{1}$ Иранский национальный институт океанографии и атмосферных наук, Тегеран, Иран, e-mail:p.ghafarian@inio.ac.ir
${ }^{2}$ Центр атмосферных наук и метеорологических исследований, Тегеран, Иран
Статья поступила в редакцию 01.02.2019, одобрена к печати 06.12.2019

\begin{abstract}
Изменение климата является основной проблемой последних десятилетий. Изменение климата сильно влияет на морские и прибрежные районы. Чтобы исследовать влияние изменения климата на южном побережье Каспийского моря, в течение 20-летнего периода исследуются изменения основных метеорологических параметров, таких как температура двухметрового уровня, относительная влажность, температура поверхности моря и количество осадков, а также туманные и пыльные дни в период с 1999 по 2018 гг. Анализируются закономерности аномалий давления на уровне моря, а также высота и температура геопотенциала уровня 500 гПа в наиболее теплые сезоны и сезоны с минимальными осадками. Для этой цели использованы различные наборы данных, такие как синоптические данные наблюдений и данные повторного анализа (NCEP / NCAR и ECMWF). Результаты исследования показали, что потепление температуры поверхности и изменение климата не имеют одинаковых эффектов в разных частях. Роль антропогенного воздействия на изменение климата неоспорима. Было отмечено, что тенденция к повышению температуры наблюдалась на всех исследованных станциях, при этом изменения параметров атмосферы, таких как влажность и осадки в разных точках оказались не идентичны, на что, по-видимому, оказывает влияние локальная топография, неконтролируемое строительство в лесных и прибрежных районах, а также прочие факторы, играющие эффективную роль в изменении влажности и условий выпадения осадков в регионах с более или менее сходным климатом.
\end{abstract}

Ключевые слова: Каспийское море, изменение климата, пыль, туман, данные реанализа

\section{Литература}

Кендэл М.Д. Ранговые корреляции / Пер. с англ., науч. ред. и предисл. Е.М. Четыркина и P.М. Энтова. - Москва: Статистика, 1975. 214 с.

Akhani H., Djamali M., Ghorbanalizadeh A., Ramezani E. Plant biodiversity of Hyrcanian relict forests, $\mathrm{N}$ Iran: an overview of the flora, vegetation, palaeoecology and conservation // Pak. J. Bot. 2010. Vol. 42. P. 231-258.

Berg N., Hall A. Increased Interannual Precipitation Extremes over California under Climate Change // Journal of Climate. 2015. Vol. 28. No. 16. P. 6324-6334.

Cuo L., Beyene T.K., Voisin N., Su F., Lettenmaier D.P., Alberti M., Richey J.E. Effects of midtwenty-first century climate and land cover change on the hydrology of the Puget Sound basin, Washington // Hydrol. Processes. 2011. Vol. 25. P. 1729-1753. DOI: 10.1002/ hyp. 7932.

Darzi N.A., Karandish F. Rice Cultivation Management in Mazandaran Province under Climate Change // Journal of Water Research in Agriculture. 2016. Vol. 30.3(3). P. 333-346. DOI: 10.22092/jwra.2016.107154. 
Ghafarian P., Negah S., Mojtahedi M., Abed H. Simulation of dust emission from the Turkmenistan desert to the southern coast of the Caspian Sea // Journal of Applied Geosciences Research. 2016. Vol. 15(38). P. 141-164.

Ghafarian P., Pegahfar N., Owlad E. Multiscale analysis of lake-effect snow over the southwest coast of the Caspian Sea (31 January-5 February 2014) // Weather. 2018. Vol. 73(1). P. 9-14.

Ghodrati A., Safaval P.A., LashtehNeshaei M.A. Climate Change Impact of the Caspian Sea Level Changes in the Quaternary Sediment // Frontiers in Environmental Engineering. 2016. Vol. 5. P. 1-10. DOI: 10.14355/fiee.2016.05.001.

Hoogewind K.A., Baldwin M.E., Rapp R.J. The Impact of Climate Change on Hazardous Convective Weather in the United States: Insight from High-Resolution Dynamical Downscaling // Journal of Climate. 2017. Vol. 30. No. 24. P. 10081-10100.

IPCC. Climate Change 2013. The Physical Science Basis. Contribution of Working Group I to the Fifth Assessment Report of the Intergovernmental Panel on Climate Change, Eds: Stocker T.F., Qin D., Plattner G.-K., Tignor M., Allen S.K., Boschung J., Nauels A., Xia Y., Bex V., Midgley P.M. Cambridge, UK and New York, NY: Cambridge University Press, 2013. 1535 p. DOI: $10.1017 / \mathrm{CBO} 9781107415324$.

Kay A.L., Jones D.A. Transient changes in flood frequency and timing in Britain under potential projections of climate change // Int. J. Climatol. 2012. Vol. 32. P. 489-502. DOI: $10.1002 /$ joc. 2288 .

KendonE.J., RowellD.P., Jones R.G., Buonomo E. Robustness of future changes in local precipitation extremes // J. Climate. 2008. Vol. 21. P. 4280-4297. DOI: 10.1175/2008JCLI2082.1.

Khadka D., Pathak D. Climate Change Projection for The Marsyangdi River Basin, Nepal Using Statistical Downscaling of GCM and Its Implications in Geodisasters // Geoenvironmental Disasters. 2016. Vol. 3. P. 15. DOI: 10.1186/s40677-016-0050-0.

Li J., Chen Y.D., Zhang L., Zhang Q., Chiew F.H.S. Future changes in floods and water availability across China:Linkage with changing climate and uncertainties // J. Hydrometeor. 2016. Vol. 17. P. 1295-1314. DOI: 10.1175/JHM-D-15-0074.1.

Mann H.B. Nonparametric tests against trend. Econometrica, 1945, Vol. 13, pp. 245-259.

Mekonnen D.F., Disse M. Analyzing The Future Climate Change of Upper Blue Nile River Basin (UBNRB) Using Statistical Down Scaling Techniques // Hydrol. Earth Syst. Sci. Discuss. 2016. DOI: 10.5194/hess-2016-543.

Min S.-K., Zhang X., Zwiers F., Shiogama H., Tung Y.-S., Wehner M. Multimodel detection and attribution of extreme temperature changes // J. Climate. 2013. Vol. 26. P. 7430-7451. DOI:10.1175/JCLI-D-12-00551.1.

Molavi-Arabshahi M., Arpe K., Leroy S.A.G. Precipitation and temperature of the southwest Caspian Sea region during the last 55 years: their trends and teleconnections with largescale atmospheric phenomena // Int. J. Climatol. 2015. Vol. 36. P. 2156-2172. DOI: $10.1002 /$ joc. 4483 .

Petrow T., Merz B. Trends in flood magnitude, frequency and seasonality in Germany in the period 1951-2002 // Journal of Hydrology. 2009. Vol. 371. P. 129-141. DOI: 10.1016/j. jhydrol.2009.03.024.

Rosenzweig C., Karoly D., Vicarelli M., Neofotis P., Wu Q., Casassa G., Menzel A., Root T.L., Estrella N., Seguin B., Tryjanowski P. Attributing physical and biological impacts to anthropogenic climate change // Nature. 2008. Vol. 453(7193). P. 353.

Sansom J., Renwick J.A. Climate change scenarios for New Zealand rainfall // J. Appl. Meteor. Climatol. 2007. Vol. 46. P. 573-590. DOI: 10.1175/JAM2491.1.

Sayad T.A., Ali A.M., Kamel A.M. Study The Impact of Climate Change on Maximum and 
Minimum Temperature Over Alexandria, Egypt Using Dtatisrtical Downscaling Model (SDSM) // Global Journal of Advanced Research. 2016. Vol. 3. No. 8. P. 694-712.

Simpkins G.R., McGregor Sh., Taschetto A.S., Ciasto L., England M.H. Tropical Connections to Climatic Change in the Extratropical Southern Hemisphere: The Role of Atlantic SST Trends // Journal of Climate. 2014. Vol. 27. No. 13. P. 4923-4936. https://doi.org/10.1175/ JCLI-D-13-00615.1.

Trapp R.J., Hoogewind K.A. The realization of extreme tornadic storm events under future anthropogenic climate change. Journal of Climate, 2016, Vol. 29(14), P. 5251-5265.

WMO, 2017, https://public.wmo.int/en/media/press-release/wmo-confirms-2017-among-threewarmest-years-record.

WMO, Manual on Codes International Codes, Volume I.1, Annex II to the WMO Technical Regulations, Part A - Alphanumeric Codes / WMO- No. 306, 2011 edition, Updated in 2018, ISBN: 978-92-63-10306-2.

Yang T., Shao Q., Hao Z.-C., Chen X., Zhang Z., Xu C.-Y., Sun L. Regional frequency analysis and spatio-temporal pattern characterization of rainfall extremes in the Pearl River basin // China. J. Hydrol. 2010. Vol. 380. P. 386-405. DOI: 10.1016/j.jhydrol.2009.11.013.

Zhang D.-L., Lin Y., Zhao P., Yu X., Wang S., Kang H., Ding Y. The Beijing extreme rainfall of 21 July 2012:"Right results" but for wrong reasons // Geophys. Res. Lett. 2013. Vol. 40. P. 1426-1431. DOI: 10.1002/grl.50304.

Zhang H., Fraedrich K., Blender R., Zhu X. Precipitation extremes in CMIP5 simulations on different time scales // J. Hydrometeor. 2013. Vol. 14. P. 923-928. DOI: 10.1175/ JHM-D-12-0181.1.

Zhang H., Wu Ch., Chen W., Huang G. Assessing the Impact of Climate Change on the Waterlogging Risk in Coastal Cities: A Case Study of Guangzhou, South China // Journal of Hydrometeorology. 2017. Vol. 18. No. 6. P. 1549-1562. https://doi.org/10.1175/ JHM-D-16-0157.1. 